\title{
Improved per hectare production in a lamb finishing system using mixtures of red and white clover with plantain and chicory compared to ryegrass and white clover
}

\author{
P.R. Kenyon ${ }^{a, *}$, P.C.H. Morel ${ }^{a}$, R.A. Corner-Thomas ${ }^{a}$, H.L. Perez ${ }^{b}$, S.C. Somasiri ${ }^{a, c}$, P.D. Kemp ${ }^{a}$, \\ S.T. Morris ${ }^{\mathrm{a}}$ \\ a International Sheep Research Centre, Institute of Veterinary, Animal and Biomedical Sciences, Massey University, Palmerston North, 4442, New Zealand \\ b São Paulo State University, Department Animal Science, Brazil \\ ${ }^{\mathrm{c}}$ Coconut Research Institute, Bandirippuwa Estate, Lunuwila, Sri Lanka
}

\section{A R T I C L E I N F O}

\section{Keywords:}

Plantago lanceolata

Cichorium intybus

Trifolium repens

Trifolium pratense

Lamb production

Carcass

Forage

Pasture

\begin{abstract}
A B S T R A C T
Over a three year period the performance of lambs being finished on three sward treatments were compared. The three treatments included (i) 'Grass-clover mixture'; perennial ryegrass (Lolium perenne L.) and white clover (Trifolium repens) (ii) 'Plantain-clover mixture'; plantain (Plantago lanceolata), white clover and red clover (Trifolium pratense) (iii) 'Chicory-plantain-clover mixture'; plantain, chicory (Cichorium intybus L.), white- and red-clover. Each year was divided into five grazing periods namely; winter, early spring, late-spring, summer and autumn with only the Grass-clover mixture being utilised in the winter due to the growth profile and management requirements of the herb species. Over the three year period, a total of $3353 \mathrm{~kg}$ live weight per ha was produced on the Grass-clover mixture, which was less $(\mathrm{P}<0.05)$ than the $3838 \mathrm{~kg} / \mathrm{ha}$ produced with the Plantain-clover mixture or $3768 \mathrm{~kg} / \mathrm{ha}$ on the Chicory-plantain-clover mixture. Similarly over the three year period, $1270 \mathrm{~kg}$ of carcass weight gain per ha was produced on the Grass-clover mixture, which was less $(\mathrm{P}<0.05)$ than the $1706 \mathrm{~kg} / \mathrm{ha}$ produced with the Plantain-clover mixture or $1732 \mathrm{~kg} / \mathrm{ha}$ with the Chicoryplantain-clover. This indicates that farmers aimed at lamb finishing can have some confidence that when utilising these herb-clovers mixtures they can increase lamb and meat productivity for at least three years.
\end{abstract}

\section{Introduction}

New Zealand grasslands are typically made up of perennial ryegrass (Lolium perenne L.) and white clover (Trifolium repens; Waghorn and Clark, 2004). While these swards can be productive year round, forage quality and quantity can be poor in the summer to autumn period (Waghorn and Clark, 2004), and be a limiting factor in lamb finishing systems. In New Zealand lambs are finished for slaughter all year round however, lamb growth rates vary based on season and forage type utilised. Therefore identifying the optimal forage to finish lambs on a per season, per year and a multiple year basis should improve productivity in these farming systems. Lamb live weight gains on a perennial ryegrass and white clover pasture during the summer and autumn periods have been reported to be in the range of 100-200 g/day (Fraser and Rowarth, 1996; Barry, 1998) which are lower than those reported for pure swards of plantain (Plantago lanceolate; Moorhead et al., 2002), chicory (Cichorium intybus L.; Cruickshank, 1986; Scales et al., 1995; Barry, 1998; Holst et al., 1998), red clover (Trifolium pratense; Moorby et al., 2004; Marley et al., 2005) and white clover (Cruickshank, 1986; Marley et al., 2005). These herb and clover species as monocultures or as mixtures are utilised in temperate climates in North America (Sanderson et al., 2005; Lombardi et al., 2015), Australasia (Reed et al., 2008; Raeside et al., 2014; Pembleton et al., 2016) and in Europe (Marley et al., 2003; Andersen et al., 2009) for sheep and cattle production. Recently, it has been reported that herb clover mixtures containing plantain, chicory, white and red clovers can improve lamb live weight gain and carcass weights in spring, summer and autumn (Golding et al., 2011; Cranston et al., 2015; Somasiri et al., 2015a,b; Somasiri et al., 2016a,b). These studies however were season specific while the forages utilised are perennial species and therefore productivity on both an annual and multiple year basis is of interest to farmers. A potential limitation of herb clover mixtures is that they should not be grazed in winter due to partial dormancy and slow forage growth rate (Kemp et al., 2010) and the potential for treading damage

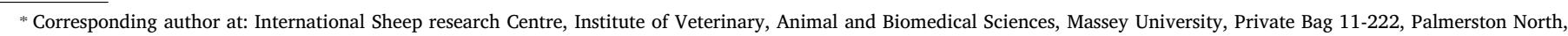
4442, New Zealand.

E-mail address: p.r.kenyon@massey.ac.nz (P.R. Kenyon). 
to the crown of plantain and chicory (Li and Kemp 2005; Kemp et al., 2010) affecting their persistency. Therefore, on an annual and multiple year per ha basis it is possible that a herb clover mixture would be less productive than a perennial ryegrass white clover sward, which can be used to finish lambs year-round. This information is unknown and is required if farmers are to make an informed decision when deciding to plant permanent forages for lamb finishing.

Therefore, the present study compares the performance of lambs over three years on three forage treatments (i) 'Grass-clover mixture' perennial ryegrass and white clover; (ii) 'Plantain-clover mixture' plantain, white clover and red clover; (iii) 'Chicory-plantain-clover mixture' plantain, chicory, white- and red-clover. Each year was divided into five grazing periods namely; winter, early spring, latespring, summer and autumn to determine productive performance over the entire year. In the winter period only the Grass-clover mixture was utilised. It was hypothesised that, on a per ha basis, the performance of lambs on the herb clover mixtures would be greater than those on the Grass-clover mixture annually, and also cumulatively over the entire three years.

\section{Materials and methods}

\subsection{Experimental site}

The study was completed over three consecutive years (2011/2012 (Year one), 2012/2013 (Year two) and 2013/14 (Year three)) with each year divided into five periods namely; winter, early spring, late-spring, summer and autumn). Each 'study year' began in winter (the June to August period). The total yearly rain fall between June and May were $1009 \mathrm{~mm}, 865 \mathrm{~mm}$ and $771 \mathrm{~mm}$ for years one, two and three, respectively (National Institute of Water and Atmospheric Research, Weather station E0536D, $40^{\circ} 38^{\prime} \mathrm{S}$ and $175^{\circ} 61^{\prime} \mathrm{E}$ )

Data collected in the periods of early spring, late-spring, summer and autumn in 2011/2012 and 2012/2013 only, have been previously published in Somasiri et al. (2015a,b, 2016a,b) individually based on each season and without examination on a per year basis. In addition the data presented in these studies did not include Year three nor did they include the winter period. The number of grazing days for each of the finishing periods are given in Table 1 . The experimental site was situated between $40^{\circ} 21^{\prime} \mathrm{S}$ and $175^{\circ} 37^{\prime} \mathrm{E}$ on the Moginie Pasture and Crop Research Unit, Massey University, $4 \mathrm{~km}$ south of Palmerston North, New Zealand with an altitude of $30 \mathrm{~m}$ (shortest day 21 June). The soil type was Tokomaru Silt Loam which is imperfectly to very poorly drained due to a fragipan (Cowie and Rijkse, 1977). This study was conducted with the approval of the Massey University Animal Ethics Committee.

Three forage treatments were compared (i) 'Grass-clover mixture' perennial ryegrass (Lolium perenne L.) cultivar One50 and white clover (Trifolium repens) cultivar Bounty; (ii) 'Plantain-clover mixture' plantain (Plantago lanceolata) cultivar Ceres Tonic, white clover and red clover (Trifolium pratense) cultivar Sensation; (iii) 'Chicory-plantain-clover mixture' plantain, chicory (Cichorium intybus L.) cultivar Puna II, whiteand red-clover using the same cultivars. All forage treatments were on the same experimental site. The Grass-clover mixture was used in all of the five periods but the Plantain-clover and Chicory-plantain-clover mixtures were only used during early spring, late-spring, summer and autumn due to the potential issues outlined earlier.

\subsection{Forage treatments}

The Grass-clover mixture was sown in autumn 2009. The area used for both Plantain-clover mixture and Chicory-plantain-clover mixture were initially power harrowed to remove approximately $1 / 3$ of the existing two year old plantain cultivar Ceres Tonic. After which the other cultivars were sown in autumn 2011 . Sowing rates ha ${ }^{-1}$ were as follows; Grass-clover mixture, ryegrass $20 \mathrm{~kg}$ and white clover $4 \mathrm{~kg}$; Plantain-clover mixture, plantain $6 \mathrm{~kg}$, white clover $4 \mathrm{~kg}$ and red clover $6 \mathrm{~kg}$; Chicory-plantain-clover mixture, chicory $6 \mathrm{~kg}$, plantain $6 \mathrm{~kg}$, white clover $4 \mathrm{~kg}$ and red clover $6 \mathrm{~kg}$. The grazing area per forage treatment was 2.25 ha consisting of three replicates of 0.75 ha each. Each replicate was subdivided into three 0.25 ha paddocks, which were each halved using temporary electric fencing for grazing management.

Table 1

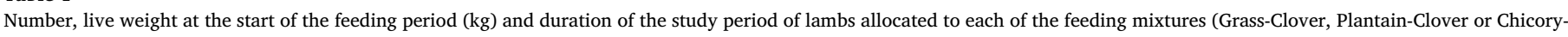
Plantain-Clover mixtures) in each season (Winter, early Spring, late-Spring, Summer and Autumn) in each of the three years of the study (Year 1-3).

\begin{tabular}{|c|c|c|c|c|c|c|c|c|c|}
\hline \multirow[t]{3}{*}{ Season } & \multicolumn{9}{|c|}{ Mixture } \\
\hline & \multicolumn{3}{|c|}{ Grass-Clover } & \multicolumn{3}{|c|}{ Plantain-Clover } & \multicolumn{3}{|c|}{ Chicory-Plantain-Clover } \\
\hline & $\mathrm{n}^{\mathrm{a}}$ & $\begin{array}{l}\text { Start live } \\
\text { weight }(\mathrm{kg}) \\
\left(\text { Mean } \pm \mathrm{SD}^{\mathrm{b}}\right)\end{array}$ & $\begin{array}{l}\text { Duration } \\
\text { (days) }\end{array}$ & $\mathrm{n}$ & $\begin{array}{l}\text { Start live } \\
\text { weight }(\mathrm{kg})(\text { Mean } \pm \text { SD) }\end{array}$ & $\begin{array}{l}\text { Duration } \\
\text { (days) }\end{array}$ & $\mathrm{n}$ & $\begin{array}{l}\text { Start live } \\
\text { weight }(\mathrm{kg}) \\
(\text { Mean } \pm \mathrm{SD})\end{array}$ & $\begin{array}{l}\text { Duration } \\
\text { (days) }\end{array}$ \\
\hline & Yea & & & & & & & & \\
\hline Winter & 44 & $36.0 \pm 0.51$ & 56 & - & - & - & - & - & - \\
\hline Early spring & 69 & $41.4 \pm 0.40$ & 28 & 69 & $41.2 \pm 0.40$ & 28 & 57 & $41.3 \pm 0.44$ & 28 \\
\hline Late-spring & 90 & $32.4 \pm 0.35$ & 40 & 90 & $32.5 \pm 0.35$ & 40 & 90 & $32.5 \pm 0.35$ & 40 \\
\hline Summer & 48 & $32.8 \pm 0.48$ & 49 & 84 & $32.8 \pm 0.37$ & 49 & 84 & $32.8 \pm 0.37$ & 49 \\
\hline Autumn & $\begin{array}{l}57 \\
\text { Yea }\end{array}$ & $34.3 \pm 0.44$ & 35 & 65 & $34.2 \pm 0.42$ & 35 & 66 & $34.3 \pm 0.41$ & 35 \\
\hline Winter & 36 & $36.6 \pm 0.56$ & 56 & - & - & - & - & - & - \\
\hline Early spring & 66 & $34.6 \pm 0.41$ & 36 & 66 & $34.8 \pm 0.41$ & 36 & 65 & $34.9 \pm 0.42$ & 36 \\
\hline Late-spring & 90 & $32.6 \pm 0.35$ & 43 & 90 & $32.5 \pm 0.35$ & 43 & 89 & $32.6 \pm 0.36$ & 43 \\
\hline Summer & 48 & $35.9 \pm 0.48$ & 25 & 48 & $35.8 \pm 0.48$ & 25 & 66 & $35.8 \pm 0.41$ & 25 \\
\hline Autumn & $\begin{array}{l}57 \\
\text { Yea }\end{array}$ & $34.1 \pm 0.44$ & 43 & 36 & $34.2 \pm 0.56$ & 43 & 57 & $34.1 \pm 0.44$ & 43 \\
\hline Winter & 45 & $35.8 \pm 0.50$ & 75 & - & - & - & - & - & - \\
\hline Early spring & 57 & $30.9 \pm 0.44$ & 42 & 57 & $30.6 \pm 0.44$ & 42 & 57 & $30.8 \pm 0.44$ & 42 \\
\hline Late-spring & 72 & $31.2 \pm 0.40$ & 47 & 72 & $31.2 \pm 0.40$ & 47 & 72 & $31.2 \pm 0.40$ & 47 \\
\hline Summer & 48 & $34.0 \pm 0.48$ & 28 & 48 & $34.0 \pm 0.48$ & 28 & 57 & $34.1 \pm 0.44$ & 28 \\
\hline Autumn & 45 & $35.1 \pm 0.50$ & 35 & 15 & $35.1 \pm 0.87$ & 35 & 30 & $35.1 \pm 0.61$ & 35 \\
\hline
\end{tabular}

${ }^{\mathrm{a}} \mathrm{n}=$ number of lambs.

${ }^{\mathrm{b}} \mathrm{SD}=$ standard deviation. 


\subsection{Animal management}

The numbers of lambs, their starting live weight, the duration of the respective study periods are presented in Table 1 . In all periods over the three years, lambs entering the forage treatments were balanced for live weight. All lambs were males and within each study were either all cryptorchid or entire males. Further in all periods lambs were orally drenched on day one $\left(D_{1}\right)$ with Ancare 'Matrix' triple combination drench (active ingredients $1 \mathrm{~g} 1$ Abamectin $^{-1} ; 40 \mathrm{~g} 1$ Levamisole $\mathrm{HCL}^{-1}$; $22.7 \mathrm{~g} 1$ Oxfendazole $^{-1}$ ) at a rate of $1 \mathrm{ml} 5 \mathrm{~kg}$ live weight ${ }^{-1}$ (Merial Ancare, Manukau City, New Zealand) and additionally re-drenched after 21 days if the individual study period was long enough to deem this necessary and suitable due to withholding periods for meat post drenching.

Lambs were always offered ad-lib feed requirements based on predicted forage growth (Matthews et al., 1999; Li and Kemp, 2005; Powell et al., 2007; Kemp et al., 2010) being equal to, or greater than, maximum lamb intake (Kenyon and Webby, 2007) for a given time of year. To ensure $a d$-lib feeding conditions lambs were moved into a new paddock within the replicate when the post-grazing sward surface height reached $5 \mathrm{~cm}$ in the Grass-clover mixture and $7 \mathrm{~cm}$ in the Plantain-clover and Chicory-plantain-clover mixtures (Kenyon and Webby, 2007; Kemp et al., 2010). The rotation length for each individual treatment depended on forage growth and therefore, movement of lambs in each forage treatment did not necessarily occur at the same time. When it was apparent ad-lib feed requirements could not be met for all forages the feeding periods were ended and the lambs slaughtered. Therefore the actual grazing period (Table 1) did not include all days within a given season. All the lambs were slaughtered at a commercial abattoir (Alliance Meat Works, Dannevirke, New Zealand).

\subsection{Measurements}

\subsubsection{Forage measurements}

The forage measurements were only undertaken in year 1 and year 2. In all treatments, four pre- and four post-grazing forage quadrat cuts $\left(0.1 \mathrm{~m}^{2}\right)$ to ground level were taken in each paddock to determine the pre- and post-grazing forage dry matter (DM) mass each time the lambs were moved into a new paddock (Brown et al., 2005). The samples were washed and dried in a draught oven at $70{ }^{\circ} \mathrm{C}$ for a minimum of $24 \mathrm{~h}$ to allow for calculation of DM on a per ha basis.

Two cages were placed in each paddock in all treatments during the grazing period. The forage inside these cages was not disturbed during the grazing period. Two grab forage samples, where taken to match what was apparently being eaten by the lambs, were collected postgrazing and frozen at $-20^{\circ} \mathrm{C}$. Two samples were then randomly selected out of six samples per treatment (two samples paddock ${ }^{-1} \mathrm{x}$ three replicates) at each post-grazing. Samples were freeze dried, ground to pass a $1 \mathrm{~mm}$ screen and analyzed for total nitrogen by "Dumas" procedure (AOAC method 968.06) using a Leco total combustion method (LECO Corporation, St. Joseph, MI, USA) and corrected for DM basis. Crude protein (CP) were calculated as $\mathrm{N} \times 6.25$.

Laboratory determination of in vitro digestibility involves comparing samples of unknown digestibility with a standard curve of samples of known in vivo digestibility. Through a hot neutral detergent rinse the soluble cell contents are removed. One hot and one or more cold $\mathrm{H}_{2} \mathrm{O}$ rinses remove the neutral detergent from the sample. After respectively 5 and $15 \mathrm{~h}$ in cellulase solution the cell walls of the sample are hydrolysed. The remaining undigested material is filtered, dried, weighed, ashed, and weighed. The procedure is able to estimate Dry Matter Digestibility (DMD), Organic Matter Digestibility (OMD), Digestible Organic Matter in the Dry Matter (DOMD) and closely follows the method of Roughan and Holland (1977). The metabolisable energy of the forage (MJ of $\mathrm{ME} / \mathrm{kg} \mathrm{DM}$ ) was calculated as DOMD $\times 0.163$ (Roughan and Holland, 1977).

\subsubsection{Animal measurements}

Lambs in each study were weighed at the start $\left(D_{1}\right)$ and at approximately fortnightly intervals and again at the end of each study within an hour of removal from the forage. The carcass weights and GR tissue depth measurements (thickness of soft tissue, predominantly fat, over 12th rib $110 \mathrm{~mm}$ from the midline of the carcass) were obtained from the abattoir at all slaughter events.

Dressing out percentage (DO\%) was calculated using the final live weight and hot carcass weight for each lamb. The carcass weight gain was calculated assuming a DO $\%$ of $40 \%$ at the start of the growing period (Kirton et al., 1984). Live weight gain and carcass weight gain within each period were calculated as the product of individual values and stocking rate per ha (SR). Cumulated live weight gain and carcass weight gain per ha were calculated as the sum of the values measured in each period over time. The yearly cumulated values were calculated as the sum of the 5 periods (winter, early spring, late-spring, summer and autumn) for the grass clover mixture and as the sum of 4 periods (forage early spring, late-spring, summer and autumn) for the forages mixtures. There were three replicates per forage treatments.

\subsubsection{Statistical analysis}

All analyses were conducted using the data collected in all three years of the experiment using SAS version 9.2 (SAS, 2012). Individual lamb data (live weight at the start of the period (LWS), live weight at the end of the feeding period (LWE), lamb live weight gain (LWG), carcass weight (CW), carcass weight gain (CWG), lamb dressing out (DO\%) and average daily gain per ha (LWGH)) were analysed using the mixed procedure (PROC MIXED) which included the fixed effects of forage treatment, season and year and their two-way and three-way interactions. The model also contained the random effect of grazing group nested in within year, season and treatment. A linear model with the fix effect of forage treatment, year and their interaction was fitted to determine the yearly cumulated carcass weight gain on a per ha basis.

The pre- and post-grazing measurement and the ME content were analysed using a linear model (PROC GLM) with the fixed effects of treatment, season and year and the interaction between season and year ( 1 and 2 only).

\section{Results}

\subsection{Forage mass and quality in year 1 and 2}

No difference $(\mathrm{P}>0.05)$ was observed between season or year for pre- and post-forage mass (Table 2). In addition no difference ( $P>0.05$ ) between treatments was observed for the pre-grazing mass measurement. The post-grazing measurements were higher for the Grass-clover mixture than the Plantain-clover and Chicory-plantainclover mixtures $(\mathrm{P}<0.05)$.

No difference $(\mathrm{P}>0.05)$ in the ME content of the forages mixture was observed between the two years. The ME content of the Grassclover mixture was lower than ME content of the Plantain-clover and Chicory-plantain-clover mixtures $(\mathrm{P}<0.05)$. The ME contents of the different forage mixture was the lowest $(\mathrm{P}<0.05)$ during summer.

\subsection{Lamb live weight}

At the beginning of the treatment period in each season the live weight of lambs in each treatment did not differ $(P>0.05)$ (Table 3$)$. There was a significant interaction between season and treatment for the live weight at the end $(\mathrm{P}<0.0001)$. At the end of the treatment period in early spring, late-pring and summer lambs offered both the Plantain-clover and Chicory-plantain-clover mixture lambs were heavier than those offered the Grass-clover mixture $(\mathrm{P}<0.05)$. In autumn lambs in the Plantain-clover mixture treatment were heavier $(\mathrm{P}<0.05)$ than those offered the Chicory-plantain-clover mixture, which in turn were heavier than those offered the Grass-clover mixture 
Table 2

The effect of forage treatments (Grass-clover mixture, Plantain-clover mixture or Chicoryplantain-clover mixture) in early spring, late-spring, summer and autumn on pre-and post-herbage mass and ME content in years 1 and 2 .

\begin{tabular}{llll}
\hline & $\begin{array}{l}\text { ME (MJ/kg } \\
\text { DM) }\end{array}$ & $\begin{array}{l}\text { Pre Grazing (kg } \\
\text { DM/ha) }\end{array}$ & $\begin{array}{l}\text { Post Grazing }(\mathrm{kg} \\
\text { DM/ha) }\end{array}$ \\
\hline $\begin{array}{llll}\text { Season } \\
\text { Winter }^{1}\end{array}$ & 9.9 & 4735 & 3320 \\
Early spring & $11.0^{\mathrm{a}}$ & 3387 & 2065 \\
Late-spring & $10.7^{\mathrm{ab}}$ & 3715 & 2510 \\
Summer & $10.5^{\mathrm{b}}$ & 4386 & 2882 \\
Autumn & $10.6^{\mathrm{b}}$ & 3840 & 2528 \\
SE & 0.07 & 387.7 & 282.7 \\
Forage & & & \\
Grass-clover mixture & $10.1^{\mathrm{c}}$ & 4417 & $3173^{\mathrm{a}}$ \\
Plantain-clover & $10.9^{\mathrm{b}}$ & 3614 & $2176^{\mathrm{b}}$ \\
$\quad$ mixture & & & $2139^{\mathrm{b}}$ \\
Chicory-plantain- & $11.1^{\mathrm{a}}$ & 3464 & 244.8 \\
$\quad$ clover mixture & & & \\
SE & 0.06 & 335.7 & 0.46 \\
P-values & & & 0.29 \\
Year & 0.5 & 0.49 & 0.02 \\
Season & 0.007 & 0.37 & 0.14 \\
Forage & $<0.0001$ & 0.9 & \\
Forage *Season & 0.43 & & \\
\end{tabular}

${ }^{1}$ Winter data are for Grass-Clover only and were not included in the statistical analysis a,b,c, Values with different superscripts indicate significant differences between season or forage $(\mathrm{P}<0.05)$.

$(\mathrm{P}<0.05)$.

\subsection{Individual lamb live weight gain}

Lamb live weight gain ( $\mathrm{g} /$ day) differed between seasons and treatments within each season $(\mathrm{P}<0.05$, Table 3$)$. There was also an interaction between season and treatment $(\mathrm{P}<0.001)$. In the Grassclover mixture the average daily live weight gain of lambs differed between all four seasons $(\mathrm{P}<0.05)$, with the greatest live weight gains observed in early spring followed by late-spring, then autumn and finally summer. In the Plantain-clover mixture, lambs had greater live weight gains during early spring than all other seasons. In late-spring and autumn live weight gains did not differ $(\mathrm{P}>0.05)$ although they were greater than in summer $(\mathrm{P}<0.05)$. In the Chicory-plantainclover mixture lamb live weight gains autumn and summer did not differ $(\mathrm{P}>0.05)$, however, they were lower than in both early and late-spring $(\mathrm{P}<0.05)$.

In early spring, late-spring and summer lamb live weight gains were greater for lambs offered the Plantain-clover and Chicory-plantainclover mixtures than the Grass-clover mixture. In autumn, lamb live weight gain differed between all three treatments $(P<0.05)$ with lambs offered the Plantain-clover mixture gaining more weight than those offered the Chicory-plantain-clover mixture which in turn gained more weight than those offered the Grass-clover mixture.

\subsection{Lamb live weight gain per hectare}

There was an interaction between season and treatment $(\mathrm{P}<0.0001)$.

The average daily gain per hectare differed between seasons within each treatment $(P<0.05)$. Lambs offered the Grass-clover mixture had the greatest average daily gain per ha in early spring followed by latespring, autumn and finally summer $(\mathrm{P}<0.05)$. In the Plantain-clover and Chicory-plantain-clover mixture treatments the greatest average daily gain per ha was seen in late-spring followed by early spring, then summer and finally autumn $(\mathrm{P}<0.05)$.

During early spring the average daily gain per ha was greater for lambs offered the Plantain-clover mixture than either the Grass-clover

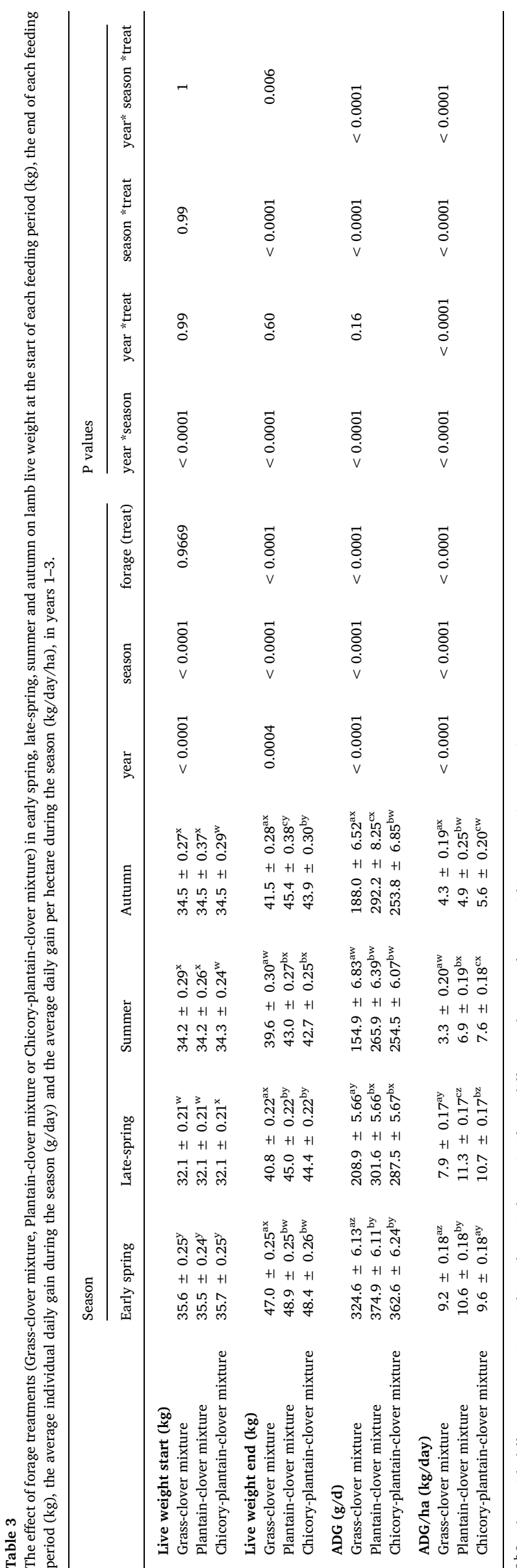




.

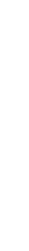

or Chicory-plantain-clover mixture $(\mathrm{P}<0.05)$. In late-spring all three treatments differed $(\mathrm{P}<0.05)$ with lambs offered the Plantain-clover mixture having greater gains the Chicory-plantain-clover mixture which in turn had greater gains than the Grass-clover mixture. In summer all three treatments again differed, however, lambs offered the Chicory-plantain-clover mixture had the greatest $(\mathrm{P}<0.05)$ gains per ha followed by the Plantain-clover mixture and finally by the Grassclover mixture. In autumn lambs offered the Grass-clover and Plantainclover mixtures had similar average daily gains per ha which were lower than seen in the Chicory-plantain-clover mixture $(\mathrm{P}<0.05)$.

\subsection{Carcass weight}

Lamb carcass weights differed between seasons and years $(\mathrm{P}<0.05$, Table 4). There was an interaction between season and treatment $(\mathrm{P}<0.001)$. Carcass weights differed between all four seasons with the heaviest carcasses in early spring followed by autumn, late-spring and finally summer $(\mathrm{P}<0.05)$. In all four seasons the carcass weight of lambs offered the Grass-clover mixture was lighter $(\mathrm{P}<0.05)$ than either the Plantain-clover or Chicory-plantain-clover mixtures. However, there was no difference observed in the carcass weight of lambs offered the Plantain-clover and Chicory-plantain-clover mixtures $(\mathrm{P}>0.05)$.

\subsection{Dressing out percentage}

There was an interaction between season and treatment $(\mathrm{P}<0.009)$. Lamb dressing out percentages differed between seasons and treatments within seasons $(\mathrm{P}<0.05)$. In early spring, late-spring and summer lambs offered the Grass-clover mixture had lower dressing out percentage than lambs on either the Plantain-clover or Chicoryplantain-clover mixtures $(\mathrm{P}<0.05)$. However, the Plantain-clover and Chicory treatments did not differ $(\mathrm{P}>0.05)$. During autumn all three treatments differed with the Chicory-plantain-clover mixture having greater dressing out percentages than the Plantain-clover treatment, which in turn was greater than the Grass-clover mixture $(P<0.05)$.

\subsection{GR tissue depth}

There was an interaction between season and treatment (P $<0.0001)$. Within each season, lambs grown on the Grass-clover mixture were leaner, i.e. had lower GR, than those grown on Plantainclover or Chicory-plantain-clover mixtures $(P<0.05)$. However, the Plantain-clover and Chicory treatments did not differ $(\mathrm{P}>0.05)$. For all the forage mixture types, lambs slaughtered in Summer had the lowest $(\mathrm{P}<0.05)$ GR depth $(\mathrm{P}<0.05)$.

\subsection{Cumulated live weight gain and carcass weight gain per ha on a yearly and three yearly basis}

There was an interaction between year and treatment $(\mathrm{P}<0.001)$. The yearly live gain weight gain per ha on the Grass-Clover mixture (Table 5) was lower $(\mathrm{P}<0.05)$ than both Plantain-clover and Chicoryplantain-clover mixtures in years, one and two and similar in year three. The Plantain-Clover mixture had a greater $(P<0.05)$ yearly live weight gain than the Chicory-plantain-clover mixture in year one and identical in years two and three.

There was an interaction between year and treatment $(\mathrm{P}<0.001)$. The yearly cumulated carcass weight gain per ha on the Grass-Clover mixture (Table 5) was lower $(\mathrm{P}<0.05)$ than both Plantain-clover and Chicory-plantain-clover mixtures in years, one and two but only lower $(\mathrm{P}<0.05)$ than the Chicory-plantain-clover mixture in year three. The Plantain-Clover mixture had a greater $(\mathrm{P}<0.05)$ yearly carcass gain than the Chicory-plantain-clover mixture in year one but lower $(\mathrm{P}<0.05)$ in year three.

Over the three year period, a total of $3353 \mathrm{~kg}$ live weight per ha was 
Table 5

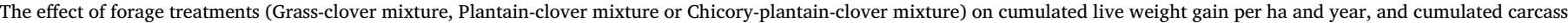
weight gain per ha and year during the three years.

\begin{tabular}{|c|c|c|c|c|c|c|}
\hline & \multicolumn{3}{|l|}{ Year } & \multicolumn{3}{|l|}{$P$ values } \\
\hline & 1 & 2 & 3 & year & forage & year *forage \\
\hline \multicolumn{7}{|l|}{ Cumulated live weight kg/ha } \\
\hline Grass-clover mixture & $1047.4 \pm 20.33^{\mathrm{a}}$ & $1177.8 \pm 20.33^{\mathrm{b}}$ & $1128 \pm 20.33^{\mathrm{b}}$ & $<0.0001$ & $<0.0001$ & $<0.0001$ \\
\hline Plantain-clover mixture & $1472.5 \pm 20.33^{\mathrm{e}}$ & $1246.9 \pm 20.33^{\mathrm{c}}$ & $1119.3 \pm 20.33^{\mathrm{b}}$ & & & \\
\hline Chicory-plantain-clover mixture & $1312.5 \pm 20.33^{\mathrm{d}}$ & $1307.1 \pm 20.33^{\mathrm{cd}}$ & $1148.9 \pm 20.33^{\mathrm{b}}$ & & & \\
\hline \multicolumn{7}{|l|}{ Cumulated carcass weight $\mathrm{kg} / \mathrm{ha}$} \\
\hline Grass-clover mixture & $412.9 \pm 12.34^{\mathrm{a}}$ & $451.8 \pm 12.34^{\mathrm{b}}$ & $405.4 \pm 12.34^{\mathrm{a}}$ & $<0.0001$ & $<0.0001$ & $<0.0001$ \\
\hline Plantain-clover mixture & $725.0 \pm 12.34_{e}$ & $564.9 \pm 12.34^{c}$ & $417.1 \pm 12.34^{\mathrm{a}}$ & & & \\
\hline Chicory-plantain-clover mixture & $668.8 \pm 12.34_{d}$ & $601.1 \pm 12.34^{\mathrm{c}}$ & $462.8 \pm 12.34^{\mathrm{b}}$ & & & \\
\hline
\end{tabular}

a,b,c,d,e Values with different superscripts indicate significant differences between forage x year combinations $(P<0.05)$.

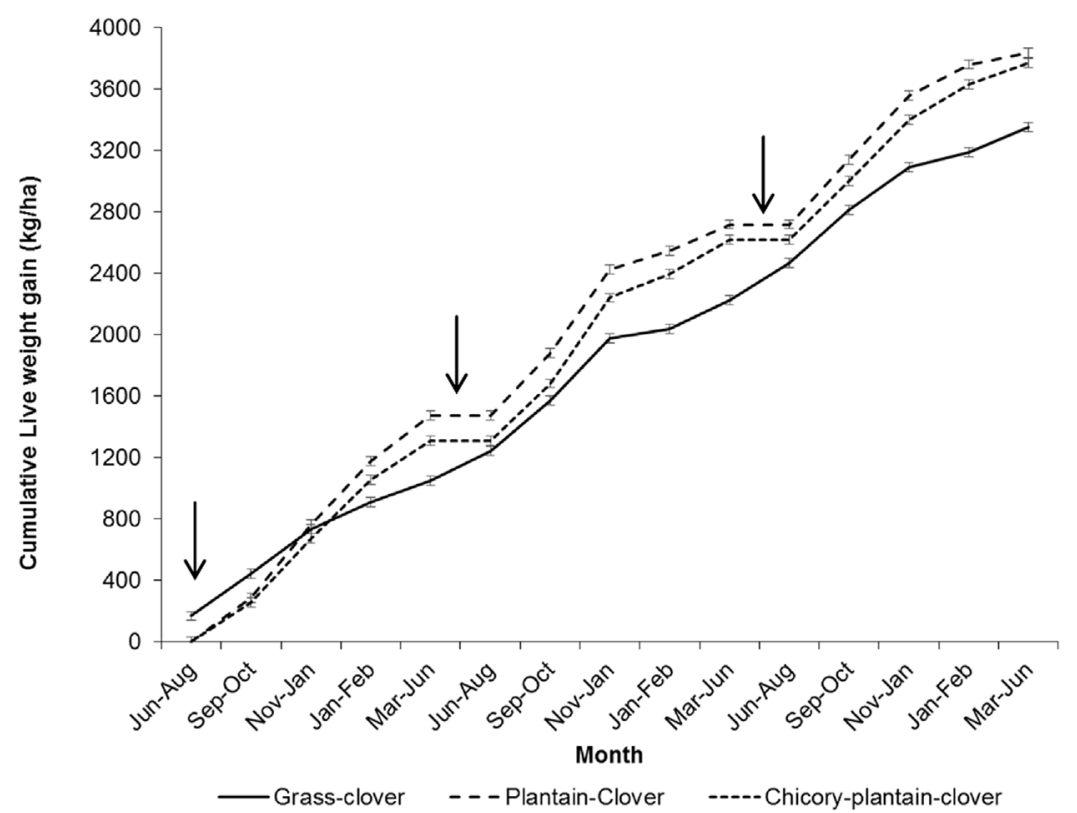

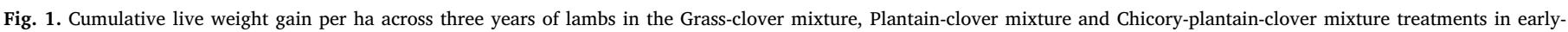
Spring, late-Spring, Summer, Autumn and Winter (arrows, indicating lambs not on all mixtures).

produced on the Grass-clover mixture, which was less $(\mathrm{P}<0.05)$ than the $3838 \mathrm{~kg} / \mathrm{ha}$ produced with the Plantain-clover mixture or $3768 \mathrm{~kg}$ / ha on the Chicory-plantain-clover mixture (Fig. 1).

Over the three year period, $1270 \mathrm{~kg}$ of carcass weight gain per ha was produced on the Grass-clover mixture, which was less $(\mathrm{P}<0.05)$ than the $1706 \mathrm{~kg} / \mathrm{ha}$ produced with the Plantain-clover mixture or $1732 \mathrm{~kg} / \mathrm{ha}$ with the Chicory-plantain-clover (Fig. 2). It is worthwhile noting that after only two years on the Plantain-clover mixture $(1289 \mathrm{~kg} / \mathrm{ha})$ or the Chicory-plantain-clover mixture $(1269 \mathrm{~kg} / \mathrm{ha}) \mathrm{a}$ similar amount of carcass weight per ha was produced as on the Grassclover mixture over three years.

\section{Discussion}

Previous studies examining distinct intervals, over a two year period, have shown that herb clover mixes can result in increased lamb growth and carcass production compared to a ryegrass white clover sward (Somasiri et al., 2015a,b; Somasiri et al. 2016a,b). The ryegrass white clover sward was found to be of poorer quality, especially in the summer-autumn period. However, as all species in the mixes are perennial, productivity on both an annual and multiple year basis is of interest to farmers, especially since the ryegrass white clover sward can be grazed in winter, while the herb clover cannot. Therefore this paper presents three years of accumulated data. The first hypothesis stated that the performance of lambs on the herb clover mixtures would be greater than those on the Grass-clover mixture in the four periods in which lambs were grazed on these forage mixtures. This hypothesis was supported over the three year period with daily lamb growth rates and therefore final live weights being greater on the two herb clover mixtures than on the Grass clover mixture, supporting previous findings (Golding et al., 2011; Somasiri et al., 2015a,b; Somasiri et al. 2016a,b). In addition, the greater final live weights and dressing out percentages on the herb clover mixtures had an additive effect resulting in greater carcass weights. There were relatively small differences between the two herb clover mixtures over the three years with farmer's choice probably depending on whether they preferred the better lamb performance on Plantain-clover in the first year versus the better performance from the Chicory-Plantain-clover in the drier third year.

Farmers in many production systems are paid on a per $\mathrm{kg}$ carcass weight basis. Therefore under these circumstances the value of the lambs at slaughter in all four periods would have been greater on the herb clover mixes than on the Grass clover mixture, even though GR depths were greater. The GR depths of the herb clover mixtures were not at a depth in which carcass values would be penalised in New Zealand (New Zealand Meat Board, 2004). The greater lamb performance on the herb clover mixtures was driven by greater forage quality rather than forage availability. However, the design of these studies did not allow for exact measurement of what the lambs consumed. 


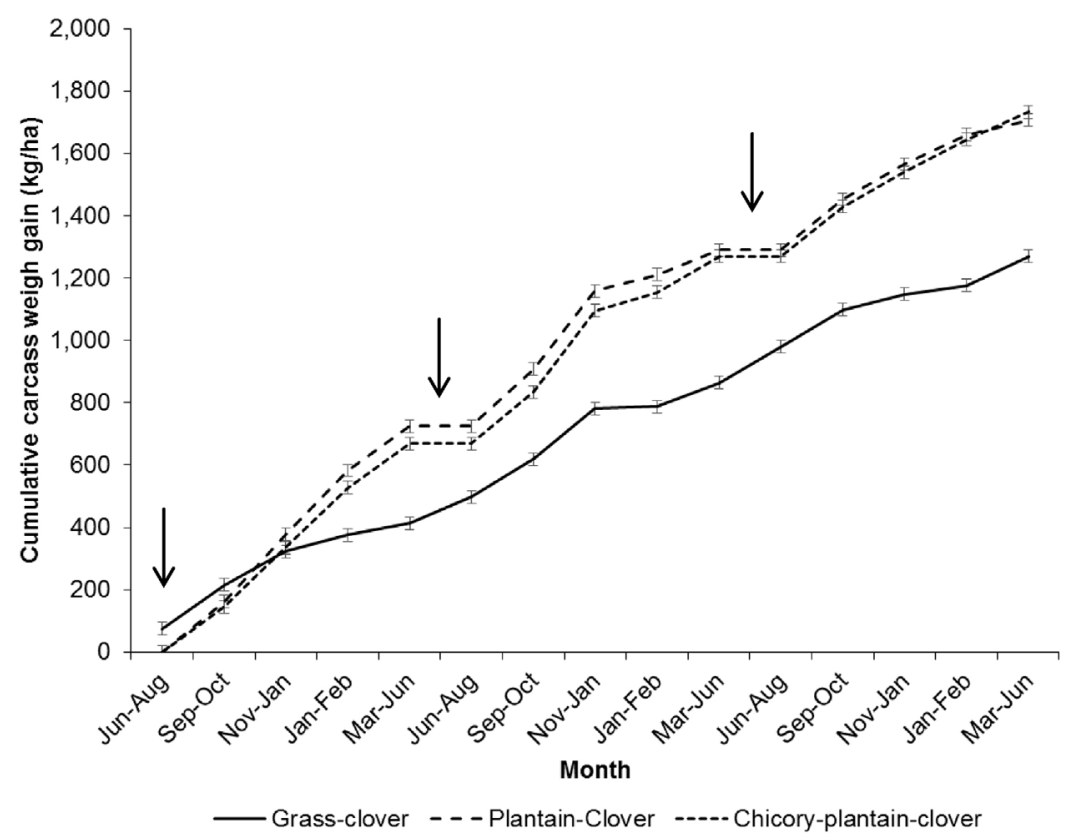

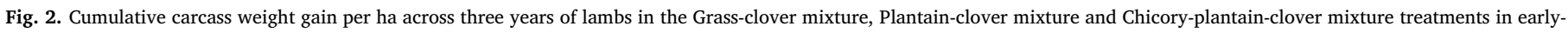
spring, late-Spring, Summer, Autumn and Winter (arrows, indicating lambs not on all mixtures).

Although, it has been previously reported that the herb clovers mixtures have greater, or tend to have greater, OMD and ME than ryegrass pasture (Kenyon et al., 2010; Golding et al., 2011; Hutton et al., 2011). Pre-grazing forage masses in the present study did not differ between treatments and the post-grazing masses were greatest on the Grass clover mixture, and on all treatments the post grazing treatments indicate forage intake was not restricted. However it is acknowledged that the relatively high pre-grazing masses could have contributed to the herbage quality of the Grass-clover mix by negatively affecting the proportion of the clover present. At a lower mass the percentage of the clover may have been greater, due to less competition which could have improved herbage quality, although this is not known.

In autumn there were slight differences between the Plantain-clover and the Chicory-Plantain-clover mixtures for average daily gain, final live weight and dressing out percentage although, no difference in carcass weight was found. While, in the other three periods the two herb clover mixtures did not differ in any of the lamb performance measures. Given that farmers are paid on either a live weight or carcass weight basis, these combined data indicate that for finishing lambs for slaughter, in the four periods in which all treatments were utilised, both herb-clover treatments are suitable options for finishing lambs.

Although previous studies and the present study have shown that herb clover mixtures can result in increased lamb performance on a per season basis from spring to autumn, annual per ha annual lamb performance has not been evaluated to date. Given that lambs cannot be finished over the winter period on the herb-clover mixtures, while they can be on the Grass-clover mixture, annual and cumulative total carcass production might be less on the herb-clover mixtures. To test this, data over multiple years is needed, as found in the present analysis. If it was found that annual lamb production was less on the herb-clover mixtures, farmers may be less willing to utilise the herbclover mixtures.

However after this point, due to a combination of faster individual lamb growth rates, heavier slaughter weights, greater dressing out percentages and higher stocking rates in some periods, per ha carcass production was greater after seven months, on the forage-clover mixtures. Further on a per year basis, both forage-clover mixtures produced more carcass in years one and two than the Grass-clover mixture, and in year three the Chicory-plantain-clover mixture produced greater per ha carcass production. Combined these results indicates that the herb-clover options are not only an effective short term option for finishing lambs, but over a three cumulative year period at least, they can be used to improve lamb production even though they could not be utilised in the winter period. Finishing lambs during the winter can be highly profitable in the New Zealand sheep production system so it is accepted that even on a farm focussed primarily on lamb finishing there can be a need for some ryegrass based pastures.

\section{Conclusion}

In support of previous studies, individual lamb productivity in terms of lamb growth, slaughter weight, dressing out percentage and carcass weight were greater on the herb-clover mixtures than on the Grassclover mixture during the period from spring to autumn. Therefore herb-clover mixtures, under the current environmental conditions, are a more suitable for finishing lambs than a grass clover mixture in these periods. When the data were combined over a three year period, including the winter period when lambs did not graze the herb-clover mixtures, annual and cumulative lamb productivity was greater on the herb-clover mixtures. This indicates that farmers aimed at lamb finishing can have some confidence that when utilising these herbclovers mixtures they can increase lamb and meat productivity for at least three years.

\section{Acknowledgements}

The authors acknowledge M. Osborne, S. Orsborn, D. Burnham, G. Purchas who provided the technical assistance with pasture and animal measurements and the International Sheep Research Centre and Massey University and the National Research Centre for Growth and Development for funding this research.

\section{References}

Andersen, C., Nielsen, T.S., Purup, S., Kristensen, T., Eriksen, J., Soegaard, K., Sorensen, J., Frette, X.C., 2009. Phyto-oestrogens in Herbage and milk from cows grazing white clover, red clover, Lucerne or chicory-rich pastures. Animal 3 (8), 1189-1195.

Barry, T.N., 1998. The feeding value of chicory (Cichorium intybus) for ruminant livestock. J. Agric. Sci. 131, 251-257.

Brown, H.E., Moot, D.J., Pollock, K.M., 2005. Herbage production, persistence, nutritive characteristics and water use of perennial forages grown over 6 years on a Wakanui 
silt loam. N.Z. J. Agric. Res, 48, 423-439.

Cowie, J.D., Rijkse, W.C., 1977. Soils of Manawatu County, North Island, New Zealand. New Zealand Soil Survey Report 30. New Zealand Soil Bureau, Department of Scientific and Industrial Research, Wellington, New Zealand.

Cranston, L.M., Kenyon, P.R., Morris, S.T., Kemp, P.D., 2015. A review of the use of chicory, plantain, red clover and white clover in a sward mix for increased sheep and beef production. J. N.Z. Grassl. 77, 89-94.

Cruickshank, G.J., 1986. Nutritional Constraints to Lamb Growth at Pasture. University of Canterbury, New Zealand (PhD Thesis).

Fraser, T., Rowarth, J., 1996. Legumes, herbs or grass for lamb performance? Proc. N.Z. Grassl. Assoc. 58, 49-52.

Golding, K.P., Wilson, E.D., Kemp, P.D., Pain, S.J., Kenyon, P.R., Morris, S.T., Hutton, P.G., 2011. Mixed herb and legume pasture improves the growth of lambs post weaning. Anim. Prod. Sci. 51, 717-723.

Holst, P.J., Kemp, D.R., Doodacre, M., Hall, D.G., 1998. Summer lamb production from puna chicory (Cichorium intybus) and Lucerne (Medicago sativa). Proc. Aust. Soc. Anim. Prod. 22, 145-148.

Hutton, P.G., Kenyon, P.R., Bedi, M.K., Kemp, P.D., Stafford, K.J., West, D.M., Morris, S.T., 2011. A herb and legume sward mix increased ewe milk production and ewe and lamb live weight gain to weaning compared to a ryegrass dominant sward. Anim. Feed Sci. Technol. 164, 1-7.

Kemp, P.D., Kenyon, P.R., Morris, S.T., 2010. The use of legume and herb forage species to create high performance pastures for sheep and cattle grazing systems. Rev. Bras. Zootecn. 39, 169-174.

Kenyon, P.R., Webby, R.W., 2007. Pastures and supplements in sheep production systems. In: Rattray, P.V., Brookes, I.M., Nicol, A.M. (Eds.), Pasture and Supplements for Grazing Animals. New Zealand Society of Animal Production (Occasional Publication No.14).

Kenyon, P.R., Kemp, P.D., Stafford, K.J., West, D.M., Morris, S.T., 2010. Can an herb and white clover mix improve the performance of multiple-bearing ewes and their lambs to weaning? Anim. Prod. Sci. 50, 513-521.

Kirton, A.H., Carter, A.H., Clarke, J.N., Duganzich, D.M., 1984. Dtressing percentages of lambs. Proc. N.Z. Soc. Anim. Prod. 44, 231-233.

Li, G., Kemp, P.D., 2005. Forage chicory (Cichorium intybus L.): a review of its agronomy and animal production. Adv. Agron. 88, 187-222.

Lombardi, D., Vasseur, E., Berthiaume, R., DeVries, T.J., Bergeron, R., 2015. Feeding preferences and voluntary feed intake of dairy cows: effect of conservation and harvest time of birdsfoot trefoil and chicory. J. Dairy Sci. 98, 7238-7247.

Marley, C.L., Cook, R., Keatinge, R., Barrett, J., Lampkin, N.H., 2003. The effect of birdsfoot trefoil (Lotus corniculatus) and chicory (Cichorium intybus) on parasite intensities and performance of lambs naturally infected with helminth parasites. Vet. Parasitol. 112, 147-155.

Marley, C.L., Fraser, M.D., Fychan, R., 2005. Effect of forage legumes and anthelmintic treatment on the performance: nutritional status and nematode parasites of grazing lambs. Vet. Parasitol. 131, 267-282.

Matthews, P.N.P., Harrington, K.C., Hampton, J.G., 1999. Management of grazing systems. In: James, W., Hodgson, J. (Eds.), New Zealand Pasture and Crop Science. Oxford University Press, Auckland, New Zealand, pp. 153-174.

Moorby, J.M., Fraser, M.D., Theobald, V.J., Wood, J.D., Haresign, W., 2004. The effect of red clover formonetin content on the live weight gain, carcass characteristics and muscle equol content of finishing lambs. Anim. Sci. 79, 303-313.

Moorhead, A.J.E., Judson, H.G., Steward, A.V., 2002. Live weight gain of lambs grazing 'Ceres Tonic' plantain (Plantago lanceolata) or perennial ryegrass (Lolium perenne). Proc. N.Z. Soc. Anim. Prod. 62, 171-173.

New Zealand Meat Board, 2004. New Zealand Meat Guide to Lamb and Mutton Carcass Classification. New Zealand Meat Classification Authority, Wellington.

Pembleton, K.G., Hills, J.L., Freeman, M.J., McLaren, D.K., French, M., Rawnsley, R.P., 2016. More milk from forage: milk production, blood metabolites, and forage intake of dairy cows grazing pasture mixtures and spatially adjacent monocultures. J. Dairy Sci. 99, 3512-3528.

Powell, A.M., Kemp, P.D., Jaya, I.K.D., Osborne, M.A., 2007. Establishment, growth and development of plantain and chicory under grazing. Proc. N.Z. Grassl. Assoc. 69, 41-45.

Raeside, M.C., Nie, Z.N., Robertson, A.M., Partington, D.L., Behrendt, R., 2014. Plantain (P/antago lanceolata L.) and perennial ryegrass (Lolium perenne L.) as pregnancy and lactation feed for ewes joined at 8 months of age. Anim. Prod. Sci. 54, 1023-1029.

Reed, K.F.M., Nie, Z.N., Miller, S., Hackney, B.F., Boschma, S.P., Mitchel, M.L., Albertsen, T.O., Moore, G.A., Clark, S.G., Craig, A.D., Kearney, G., Li, G.D., Dear, B.S., 2008. Field evaluation of perennial grasses and herbs in southern Australia. 1. Establishment and forage production. Aust. J. Exp. Agric. 48, 409-423.

Roughan, P.G., Holland, R., 1977. Predicting in-vivo digestibility of forages by exhaustive enzymic hydrolysis of cell walls. J. Sci. Food Agric. 28, 1057-1064.

SAS, 2012. SAS Institute, SAS/STAT User's Guide: Statistics Version 9.2. SAS. SAS Institute Inc., Cary, NC.

Sanderson, M.A., Soder, K.J., Muller, L.D., Klement, K.D., Skinner, R.H., Goslee, S.G., 2005. Forage mixture productivity and botanical composition in pastures grazed by dairy cattle. Agron. J. 97, 1465-1471.

Scales, G.H., Knight, T.L., Saville, D.J., 1995. Effect of forage species and feeding level on internal parasites and production performance of grazing lambs. N.Z. J. Agric. Res. $38,237-247$.

Somasiri, S.C., Kenyon, P.R., Kemp, P.D., Morel, P.C.H., Morris, S.T., 2015a. Growth performance and carcass characteristics of lambs grazing forage mixes inclusive of plantain (Plantago lanceolata L.) and chicory (Cichorium intybus L.). Small Rumin. Res. 127, 20-27.

Somasiri, S.C., Kenyon, P.R., Morel, P.C.H., Kemp, P.D., Morris, S.T., 2015b. Herb-clover mixes increase lamb live weight gain and carcass weight in the autumn period. N.Z. J. Agric. Res. 58, 384-396.

Somasiri, S.C., Kenyon, P.R., Kemp, P.D., Morel, P.C.H., Morris, S.T., 2016a. Effect of herb-clover mixes of plantain and chicory on yearling lamb production in the early spring period. Anim. Prod. Sci. 56, 1662-1668.

Somasiri, S.C., Kenyon, P.R., Kemp, P.D., Morel, P.C.H., Morris, S.T., 2016b. Mixtures of clovers with plantain and chicory improve lamb production performance compared to a ryegrass-white clover sward in the late spring and early summer period. Grass Forage Sci. 71, 270-280.

Waghorn, G.C., Clark, D.A., 2004. Feeding value of pastures for ruminants. N.Z. Vet. J. 52, $320-331$. 